\title{
Effect of Hot Band Microstructure on Strength and Ductility of Cold Rolled Dual Phase Steel*
}

\author{
By Hidenori SHIRASAWA A* and J. G. THOMSON***
}

\begin{abstract}
Synopsis
The strength and ductility of cold rolled dual phase steels produced from four different hot band structures were investigated for a $0.07 \% \mathrm{C}-1.00 \%$ $\mathrm{Si}-1.54 \% \mathrm{Mn}$ steel. The hot band microstructures were: spheroidized cementite, ferrite-pearlite, bainite-ferrite and martensite. Following $50 \%$ cold rolling these were given simulated water quenching type intercritical continuous annealing treatments to produce cold rolled dual phase steel.

The distribution of low temperature transformation products (LTTP) was affected by hot band microstructure. Bainitic hot band produced the most uniform LTTP distribution with complete ferrite grain boundary coverage resulting in marked stage II work hardening seen in Jaoul-Crussard stress-strain analysis. This structure also had the highest endurance ratio in reverse bending fatigue tests. Bainitic and martensitic hot band structures developed the highest tensile strengths when processing conditions were otherwise the same. No hot band microstructure conferred superior ductility for the strength of the resulting cold rolled dual phase steel
\end{abstract}

Key words: dual phase steel; microstructure; ductility; fatigue; work hardening.

\section{Introduction}

The mechanical properties of cold rolled dual phase steels are strongly influenced by the volume fraction and distribution of martensite. This microstructure is easily developed by a process of partial austenitization during continuous annealing at intercritical temperatures, followed by water quenching.

Partial austenitization of steel during annealing has been studied by several investigators. ${ }^{1-4)}$ Garcia and Deardo ${ }^{1)}$ observed the development of austenite from different microstructures in a series of $1.5 \%$ $\mathrm{Mn}$ steels, and Yi et al. ${ }^{2)}$ studied the role of grain boundaries on the nucleation and growth behavior of austenite. Yang et al. ${ }^{3)}$ investigated ferrite recrystallization and austenite formation in a cold rolled $0.08 \% \mathrm{G}-0.2 \% \mathrm{Si}-1.45 \% \mathrm{Mn}$ pearlitic steel, and reported that recrystallization of the deformed ferrite and spheroidization of the broken cementite lamellae strongly influenced the formation and distribution of austenite and, in turn, martensite in dual phase structure.

These studies suggest that dual phase steel mechanical properties may depend on pre-annealing micro- structure but the practical significance of manipulating hot band structure with a view to controlling dual phase sheet properties has received little attention. Conventional dual phase sheet production uses ferritepearlite hot band exclusively. This investigation aimed to improve such understanding with respect to strength and ductility, as parameters important in the application of dual phase sheet to the automotive industry.

Four initial microstructures were used in this study: fine spheroidized cementite in a globular ferrite matrix (actually tempered martensite), conventional ferrite-pearlite, bainite-ferrite and martensite.

\section{Experimental Procedure}

The steel used in this study was prepared as a $40 \mathrm{~kg}$ air induction melted laboratory heat. The ingot was rough rolled to three $20 \mathrm{~mm}$ thick slabs and two were homogenized at $1250^{\circ} \mathrm{C}$ for $24 \mathrm{~h}$ in a nitrogen atmosphere. This treatment eliminated banded structures but affected the as cast composition slightly through nitrogen pick up and decarburization, as shown in Table 1 .

The homogenized slabs were reheated to $1200^{\circ} \mathrm{C}$ for hot rolling to $2.6 \mathrm{~mm}$ hot band with an $850^{\circ} \mathrm{C}$ finishing temperature, followed by air cooling to room temperature. Pieces of this material were variously heat treated to make the four hot band structures designated as follows:

(i) Steel $\mathrm{S}$ (Spheroidized Cementite)

Hot band heated in a salt bath to $975^{\circ} \mathrm{C}$, held for $10 \mathrm{~min}$ and water quenched to produce martensite which was subsequently tempered at $650^{\circ} \mathrm{C}$ for $20 \mathrm{~h}$. (ii) Steel F (Ferrite-Pearlite)

Hot band austenitized in a salt bath at $975^{\circ} \mathrm{C}$ for $10 \mathrm{~min}$ followed by air cooling to $650^{\circ} \mathrm{C}$ and a further $30 \mathrm{~min}$ hold in a salt bath at $650^{\circ} \mathrm{C}$ followed by air cooling.

(iii) Steel B (Bainite-Ferrite)

Hot band austenitized in a salt bath at $975^{\circ} \mathrm{G}$ for $10 \mathrm{~min}$ then quenched, in a second, to $400^{\circ} \mathrm{C}$ salt bath and maintained at $400^{\circ} \mathrm{G}$ for $30 \mathrm{~min}$ followed

Table 1. Chemical compositions of steels. (wt \%)

\begin{tabular}{lcccccccc}
\multicolumn{1}{c}{ Steel } & $\mathrm{C}$ & $\mathrm{Si}$ & $\mathrm{Mn}$ & $\mathrm{P}$ & $\mathrm{S}$ & $\mathrm{Al}$ & $\mathrm{N}$ \\
\hline Non-homogenized & 0.09 & 1.02 & 1.56 & 0.003 & 0.006 & 0.034 & 0.0058 \\
Homogenized & 0.07 & 1.00 & 1.54 & 0.002 & 0.005 & 0.031 & 0.0124 \\
\hline
\end{tabular}

\footnotetext{
* Based on the paper presented to the 113th ISIJ Meeting, April 1987, S512, at The University of Tokyo in Tokyo. Manuscript received on December 17, 1986; accepted in the final form on January 16, 1987. (C) 1987 ISIJ

** Kakogawa Works, Kobe Steel, Ltd., Kanazawa-cho, Kakogawa 675-01.

*** R \& D Department, Stelco Inc., Hamilton, Ontario, L8N 3T1, Canada.
} 
by air cooling.

\section{(iv) Steel M (Martensite)}

Hot band austenitized at $1050^{\circ} \mathrm{C}$ for $2 \mathrm{~min}$ then water quenched. The relatively high austenitization temperature ensured the formation of a fully martensitic structure containing no retained austenite as determined by X-ray diffraction.

The four sheets with different microstructures were all cold rolled $50 \%$ to $1.3 \mathrm{~mm}$. Simulated continuous annealing to form dual phase structures was performed in salt baths by heating at approximately $14^{\circ} \mathrm{C} / \mathrm{s}$ to $800^{\circ} \mathrm{C}$, holding $1 \mathrm{~min}$ at $800^{\circ} \mathrm{C}$, air cooling at $10^{\circ} \mathrm{C} / \mathrm{s}$ to $750^{\circ} \mathrm{C}$, water quenching, overaging at $200^{\circ} \mathrm{C}$ for $2 \mathrm{~min}$ and finally air cooling. Preliminary study indicated that the austenitization ratio of the steel at $800^{\circ} \mathrm{G}$ was about $40 \%$.

Metallographic examination, tensile testing, and fatigue tests were carried out for all dual phase steels made. For each steel three longitudinal and three transverse JIS 13B tensile specimens were pulled at room temperature in an Instron machine using a cross-head speed of $10 \mathrm{~mm} / \mathrm{min}$. The hour glass shaped fatigue specimens, shown in Fig. 1, were cut with their axes transverse to the sheet rolling direction and chemically polished at edges. These were given full reverse bending fatigue tests under load control in a Tokyokoki-Schenck-PWO machine.

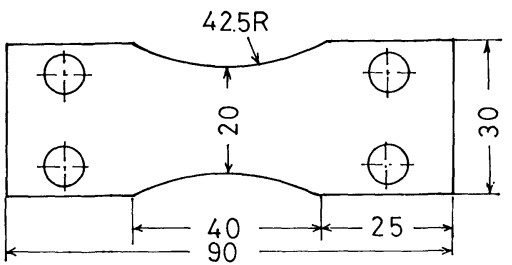

Fig. 1. Bending fatigue specimen.

\section{Experimental Results}

\section{Microstructural Observation}

Figure 2 shows the four hot band microstructures $((\mathrm{a}) \sim(\mathrm{d}))$ and those of the associated cold rolled dual phase steels $((\mathrm{e}) \sim(\mathrm{h}))$. The starting microstructure of Steel $\mathrm{S}$ is characterized by many spheroidized particles in a matrix of acicular and equiaxed ferrite. The pearlite colonies of Steel $\mathbf{F}$ starting microstructure are discrete because of the low carbon content of the steel. Steel B contains both bainite and ferrite while Steel $\mathrm{M}$ starting microstructure is fully martensitic.

Typical dual phase microstructures of ferrite and low temperature transformation products (LTTP) were developed by cold rolling and continuous annealing. For all steels, the ferrite grain size was less than $20 \mu \mathrm{m}$ and the measured LTTP volume fraction ranged between 27 and $31 \%$.

TEM analysis of the LTTP on the ferrite grain boundaries showed them to consist of martensite and bainite, for all starting structures (Fig. 3). Retained austenite made up less than $1 \%$ of the LTTP as revealed by X-ray diffraction. It is conspicuous,

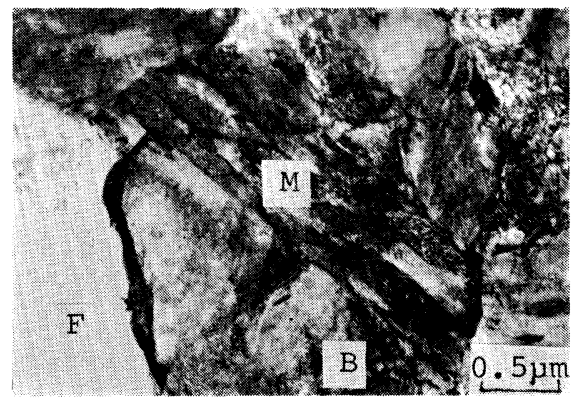

F: Ferrite, B: Bainite, M: Martensite

Fig. 3. Representative TEM microstructure of cold rolled dual phase steel (Steel B).
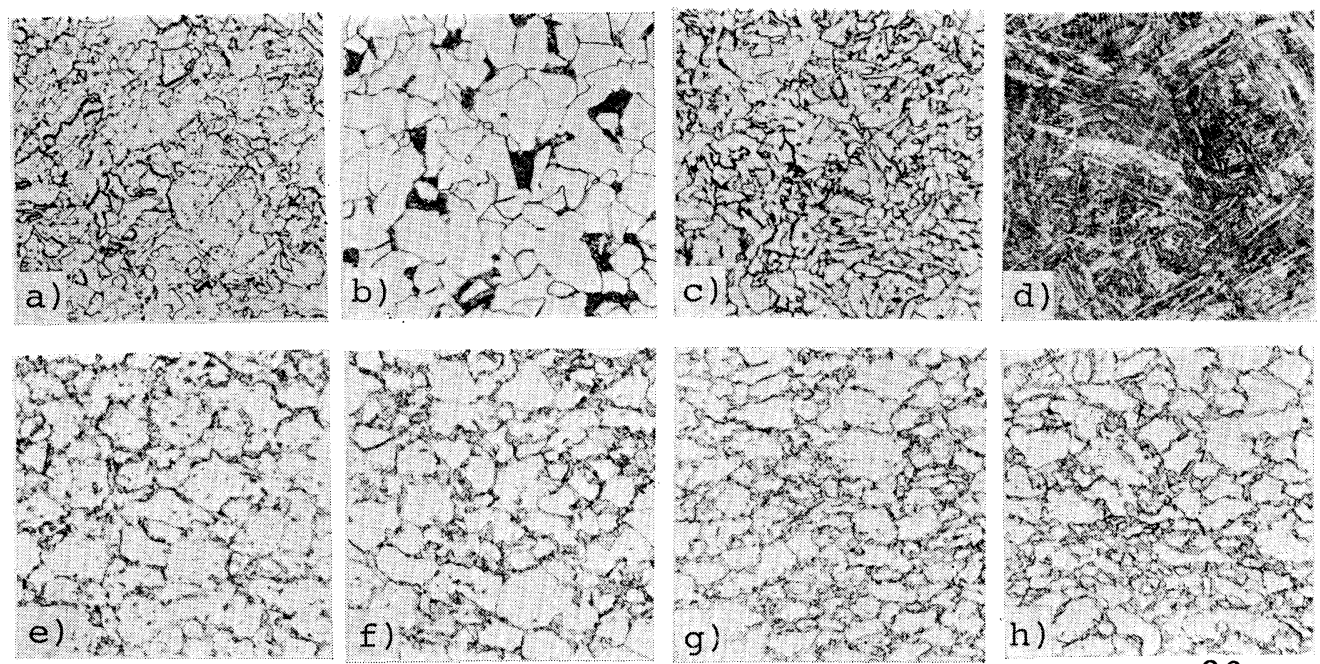

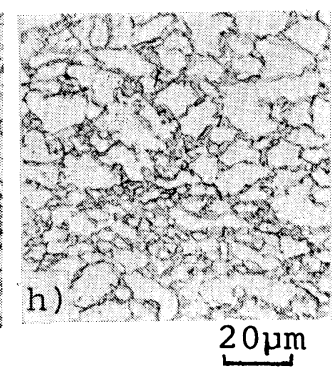

d) Steel $\mathbf{M}$

h) Steel $\mathbf{M}$

Hot bands: a) Steel S,

b) Steel F,

c) Steel B,

Fig. 2. Microstructures of cold rolled dual phase steels and their hot band structures. 
especially in Steel S, that some particles exist inside the ferrite grains as well as on the ferrite grain boundaries. SEM analysis showed these to be martensite. Garcia and Deardo ${ }^{1)}$ reported that spheroidized cementite in cold rolled ferrite does not act as austenite nucleation sites. Yi et al.'s data agree with this. ${ }^{2)}$ The different role of spheriodized cementite in this regard between these studies and ours is probably due to heating rate. They used a rather low heating rate which permitted cementite dissolution and carbon diffusion to austenite forming on ferrite grain boundaries. The more rapid heating rate used in our study could result in austenite nucleation at the cementite/ferrite interface, a mechanism advanced to explain the presence of LTTP inside ferrite grains of a dual phase steel formed from cold rolled ferrite--pearlite structure using a similar heating rate. ${ }^{3)}$

LTTP coverage of the ferrite grain boundaries varies from one starting microstructure to another. Steel $\mathrm{S}$ has incomplete coverage. In Steel $\mathrm{F}$ the LTTP are concentrated in areas previously occupied by the pearlite colonies in the cold rolled structure, as well as within the ferrite grains, leaving many ferrite/ferrite interfaces. Figure 2 shows that the bainite-ferrite prior structure produced the most uniform LTTP distribution, with complete ferrite grain boundary coverage. This is confirmed by Fig. 4, which shows the difference between Steels B and F. The martensitic prior structure gave rise to a dual phase microstructure containing microduplex regions

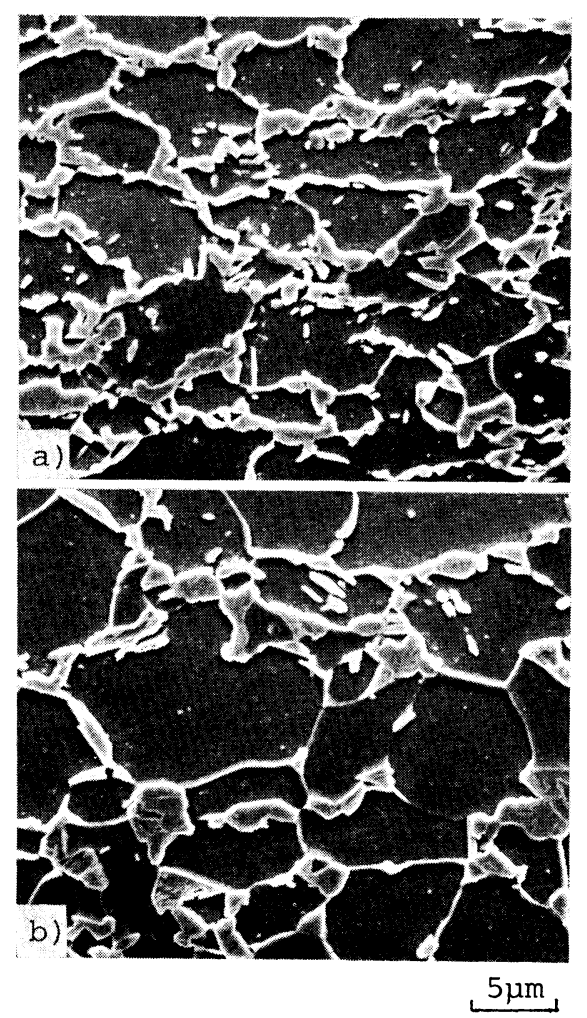

a): Steel B, b): Steel F

Fig. 4. SEM microstructures of cold rolled dual phase steels produced by bainite-ferrite and ferrite-pearlite hot bands. of very small ferrite grains surrounded by LTTP and larger ferrite grains having partial LTTP grain boundary coverage, shown in Fig. 2.

\section{Tensile Properties}

\section{Strength and Ductility}

The results of tensile testing are summarized in Table 2. Each value is an average of the rolling and transverse direction test results. There is a certain influence of starting microstructure on the tensile strength of the cold rolled dual phase steel. Steel F had the lowest $\left(71.3 \mathrm{kgf} / \mathrm{mm}^{2}\right)$ and Steel $\mathrm{M}$ the highest $\left(76.3 \mathrm{kgf} / \mathrm{mm}^{2}\right)$ average tensile strength. All steels had the low yield ratio and absence of yield point elongation characteristic of dual phase steels, even though the hard phase was not completely martensitic. Hot band microstructure did not appear to affect the strength-ductility balance.

The effect of continuous annealing soak time at $800^{\circ} \mathrm{G}$ on the tensile strengths of Steels $\mathrm{F}$ and $\mathrm{M}$, which showed the lowest and highest strengths respectively, was also investigated. The results in Fig. 5 show that longer annealing times raised tensile strength, and that this increase is larger in Steel F. This result suggests that the time taken to reach equilibrium in intercritical annealing depends on prior structure and that the advantage of using one hot band over another is optimized at short annealing times.

\section{Work Hardening Behavior}

Results of a Jaoul-Crussard stress-strain analysis are shown in Fig. 6. Each curve represents the average of three longitudinal tensile specimens for each steel. Jaoul-Crussard analysis is often used to study work hardening behavior at low strains.

Table 2. Mechanical properties of cold rolled dual phase steels produced by different hot band structures.

\begin{tabular}{ccccc}
\hline Steel & $\begin{array}{c}\text { YS } \\
\left(\mathrm{kgf} / \mathrm{mm}^{2}\right)\end{array}$ & $\begin{array}{c}\text { TS } \\
\left(\mathrm{kgf} / \mathrm{mm}^{2}\right)\end{array}$ & El $(\%)$ & Y.R. \\
\hline $\mathrm{S}$ & 40.3 & 74.2 & 19.9 & 0.54 \\
$\mathrm{~F}$ & 39.9 & 71.3 & 18.2 & 0.56 \\
$\mathrm{~B}$ & 40.1 & 74.7 & 19.8 & 0.54 \\
$\mathrm{M}$ & 41.6 & 76.3 & 19.6 & 0.55 \\
\hline
\end{tabular}

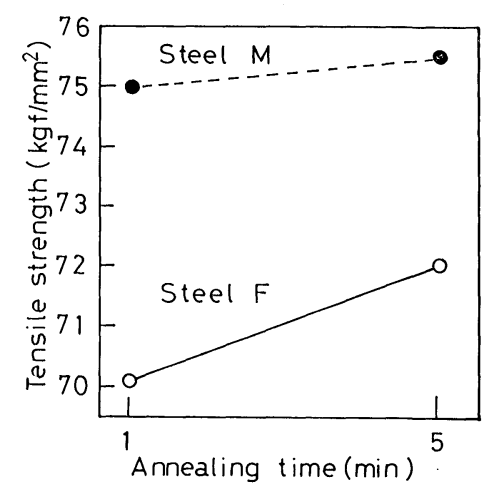

Fig. 5. Annealing time dependence of tensile strength of cold rolled dual phase steels produced by ferritepearlite and martensite hot bands. 


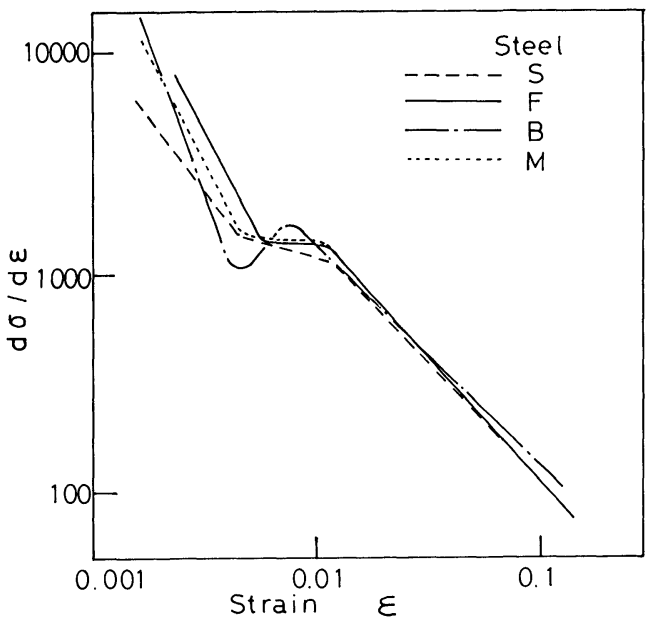

Fig. 6. Jaoul-Crussard analysis of stress-strain curves.

According to Cribb and Rigsbee ${ }^{5)}$ and Matlock et al.$^{6)}$ a $d \sigma / d \varepsilon v s$. $\varepsilon$ curve consists of three stages in the case of a dual phase steel:

(i) Stage I results from the homogeneous deformation of the ferrite matrix produced by the glide of mobile dislocations present near martensite particles.

(ii) Stage II is unique to dual phase steels and covers a period of diminished work hardening associated with constrained ferrite deformation in the presence of rigid martensite, and with the transformation of retained austenite to martensite.

(iii) Stage III begins with dislocation cell formation after which further ferrite deformation takes place by cross slip and dynamic recovery processes while martensite may deform plastically.

The onset of each stage is marked by a change in slope on the Jaoul-Crussard plot. Stage II deformation appears as a plateau, or even a slope sign change, between strains of 0.005 and 0.01 . The pronounced increase in $d \sigma / d \varepsilon$ for Steel $\mathrm{B}$ in this range sets it apart from the other steels. In this steel the ferrite deformation is strongly constrained by the complete coverage of ferrite grain boundaries by martensite. Contrary to expectations Steel S, with LTTP particles inside ferrite grains, did not show extraordinary work hardening behavior.

\section{Fatigue Properties}

Fully reversed bending fatigue test results are shown in Fig. 7. There is little scatter in the data for each steel. Steel B had the highest fatigue strength $35.7 \mathrm{kgf} / \mathrm{mm}^{2}$, at $10^{7}$ cycles compared with the other steels at approximately $30 \mathrm{kgf} / \mathrm{mm}^{2}$. This difference is not explained by the static tensile test results (Table 3).

The characteristics of fatigue crack formation and propagation in dual phase steels have been investigated with respect to the morphology of the martensitic constituent. ${ }^{7-12)}$ Suzuki and McEvily ${ }^{7)}$ reported that a steel with a continuous network of martensite around the ferrite grains had a higher $\Delta K_{t h}$ than did one with martensite islands encapsulated in a ferrite matrix. A study by Tsuzuki et al. ${ }^{8)}$ also supports the

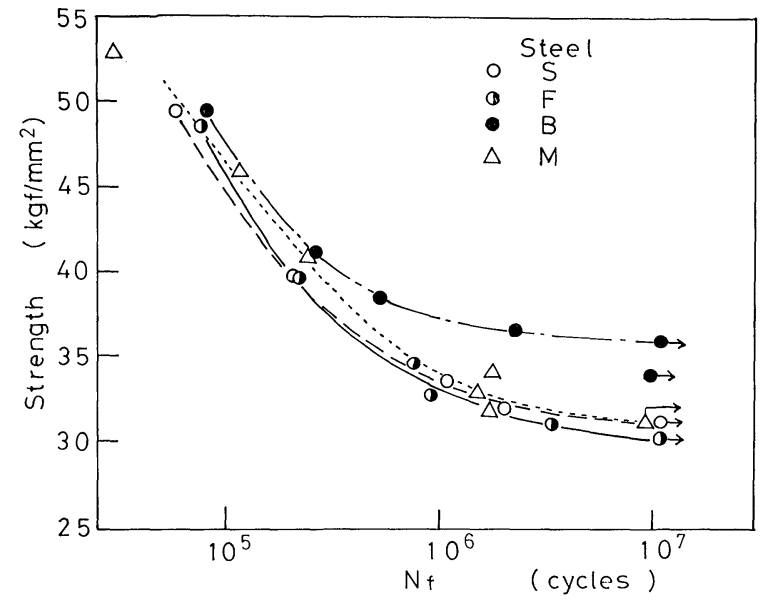

Fig. 7. Results of fully reversed bending fatigue test.

Table 3. Static tensile properties and fatigue strength.

\begin{tabular}{cccc}
\hline Steel & $\begin{array}{c}\text { YS } \\
\left(\mathrm{kgf} / \mathrm{mm}^{2}\right)\end{array}$ & $\begin{array}{c}\mathrm{TS} \\
\left(\mathrm{kgf} / \mathrm{mm}^{2}\right)\end{array}$ & $\begin{array}{c}\text { Fatigue } \\
\text { strength } \\
\left(\mathrm{kgf} / \mathrm{mm}^{2}\right)\end{array}$ \\
\hline $\mathrm{S}$ & 40.3 & 75.5 & 31.3 \\
$\mathrm{~F}$ & 39.5 & 70.5 & 30.0 \\
B & 38.1 & 73.3 & 35.7 \\
M & 40.7 & 75.1 & 31.0 \\
\hline
\end{tabular}

Note: Transverse direction.

results of our study on the difference in fatigue strength between the two microstructures. According to Sakamoto et al., ${ }^{9)}$ the plastic constraint of ferrite influences the persistent slip band formation by the heterogeneity in the density of dislocations in ferrite. Persistent slip bands form linearly in ferrite grains then grow into microscopic crack after many cycles for the steel with a continuous network of martensite around ferrite grains. The microscopic crack propagates preferentially in the ferrite then becomes the macroscopic crack. However, the microscopic crack stops when it encounters hard phase before it gains enough length or $\mathrm{K}$ to break through. ${ }^{10)}$ It seems that Steel B has the least probability of macroscopic crack formation in our study.

Fatigue crack propagation proceeded across ferrite grains and LTTP, Fig. 8. In Steel B, with its continuous network of LTTP around the ferrite grains, any crack would have to cross zones of LTTP repeatedly. LTTP would thus act as effective propagation barriers and delay crack growth ${ }^{11}$ to the critical length. Once at the critical length, the LTTP would no longer affect propagation. ${ }^{2)}$

It was expected that Steel $\mathrm{S}$ would display high low cycle fatigue strength because of a more uniform distribution of dislocations throughout the ferrite. ${ }^{13)}$ The results, however, did not bear this out.

\section{Discussion}

1. Recrystallization and Austenitization in Continuous Annealing

The uniform LTTP distribution in dual phase 
steels made from bainitic hot band results in increased work hardening rates and high fatigue strength. This result has practical significance in as much as bainitic hot band can be produced in the hot strip mill through run out table cooling control. To better understand how this favorable structure develops during continuous annealing, the austenitization of cold rolled bainite-ferrite hot band was studied in comparison with that of ferrite-pearlite hot band.

Bainite-ferrite and ferrite-pearlite starting microstructures, prepared as outlined in Chap. II. using the non-homogenized steel in Table 1, were $50 \%$ cold rolled and machined into $3 \mathrm{~mm}$ diameter $\times 10 \mathrm{~mm}$ long cylinders. These specimens were induction heated to 600,650 and $700^{\circ} \mathrm{C}$ at $10^{\circ} \mathrm{G} / \mathrm{s}$ and held there for $60 \mathrm{~s}$ before rapid cooling. Representative SEM microstructures of the quenched specimens are shown in Fig. 9.

With a bainite-ferrite starting microstructure, heating to $600^{\circ} \mathrm{C}$ caused some microstructural change. Spherical particles developed from the cold rolled bainite. Partial recrystallization also took place. On heating to $650^{\circ} \mathrm{C}$ these particles developed at the ferrite grain boundaries, as well as continuing to appear inside grains. Recrystallization continued at this stage. Further heating to $700^{\circ} \mathrm{C}$ saw austenite already formed with nearly complete ferrite grain

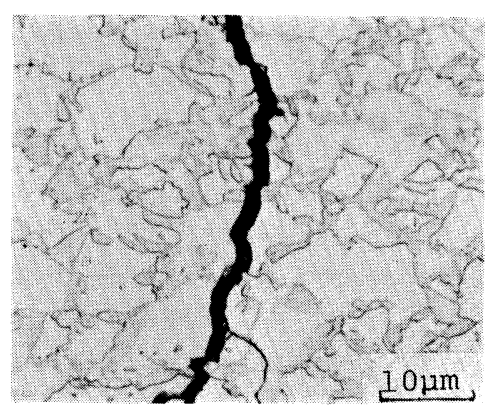

Fig. 8. Fatigue crack propagation (Steel B, Nf: $2.3 \times 10^{6}$ cycles). boundary coverage. It appears that austenite formation was accelerated by incomplete ferrite recrystallization.

In the case of cold rolled ferrite-pearlite, spheroidization of the broken cementite lamellae occurred concurrently with ferrite recrystallization with heating to $600^{\circ} \mathrm{C}$. Most spheroidized cementite particles are grouped within the area of the former pearlite colonies. When hearted to $650^{\circ} \mathrm{C}$ the spheroidization was accelerated and clusters of spheroidized particles are even observed inside ferrite grains. Recrystallization seems to be finished at this stage. At $700^{\circ} \mathrm{C}$ austenite formed predominantly at grain boundary triple points and as globular austenite within former pearlite colonies.

These observations suggest that the uniform distribution of LTTP on ferrite grain boundaries results from a uniform dispersion of spheriodized cementite before the onset of austenitization in intercritical annealing. The fragmentation and elongation of pearlite colonies in cold rolling does not afford a sufficiently uniform structure to satisfy this condition.

\section{Influence of Hot Band Microstructure on the Strength-} Ductility Balance of Cold Rolled Dual Phase Steel

It was shown that the tensile strength of cold rolled dual phase steel is not largely affected by hot band microstructure. Concerning the production of cold rolled high strength steel with good press formability, it is interesting to know how much the strengthelongation balance can be influenced by hot band microstructure.

A supplementary investigation was performed using the ferrite-pearlite, bainite-ferrite and mertensite hot band structures, prepared as before from the nonhomogenized steel in Table 1 . Cold reductions of 50 and $80 \%$, and two continuous annealing cycles, $750^{\circ} \mathrm{G} \times 2 \mathrm{~min}$ and $800^{\circ} \mathrm{G} \times 2 \mathrm{~min}$ were used. Hot band thickness was arranged so that either cold reduction would give $1 \mathrm{~mm}$ thick sheet.

Tensile strength and elongation data for each hot

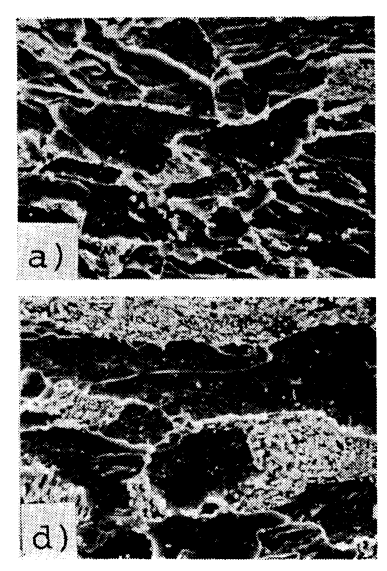

Bainite-ferrite hot band: Ferrite-pearlite hot band:
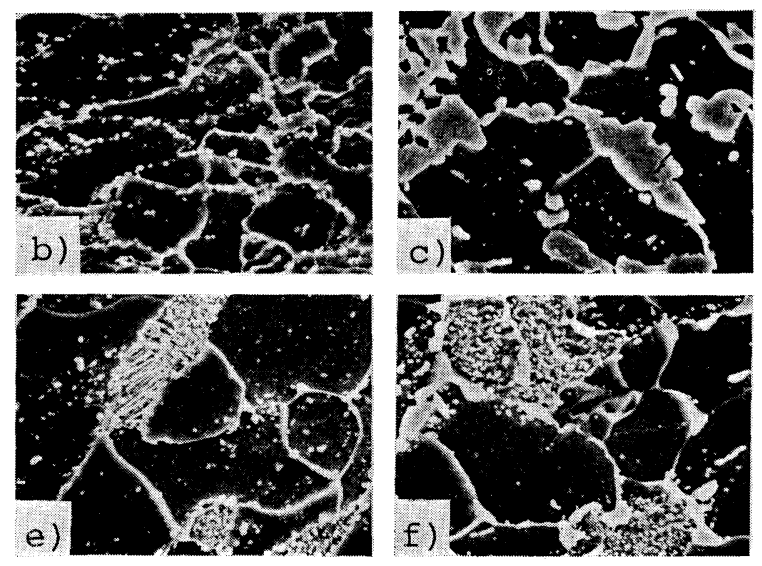

$5 \mu \mathrm{m}$
a) $600^{\circ} \mathrm{C}$,
b) $650^{\circ} \mathrm{C}$,
c) $700^{\circ} \mathrm{C}$
d) $600^{\circ} \mathrm{C}$,
e) $650^{\circ} \mathrm{C}$,
f) $700^{\circ} \mathrm{C}$

Fig. 9. Microstructural change of cold rolled ferrite-pearlite and bainite-ferrite hot bands during annealing. 


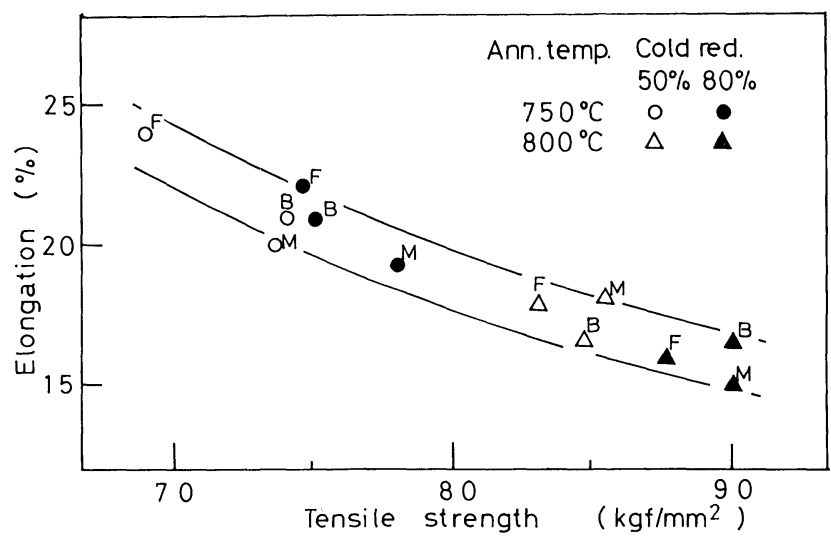

Fig. 10. Tensile strength-elongation balance of cold rolled dual phase steels produced by hot bands with different microstructures.

band microstructure were plotted in Fig. 10. Within the scatter of the data the strength-elongation balance is the same for all starting microstructures. Figure 10 , however, does give some fundamental information on strength behavior. Higher cold reduction raised tensile strength for the same starting structure. martensitic hot band gave the highest tensile strength under the same processing conditions while the ferrite-pearlite hot band gave the lowest, confirming the results in Table 2. Higher annealing temperatures reduced the strength differences associated with the various starting structures by speeding cementite dissolution and carbon diffusion so that austenite development from cold rolled structures containing larger, widely spaced cementite particles is relatively enhanced. This would result in a more similar volume fraction of LTTP after quenching.

\section{Conclusions}

(1) Optical microstructures of cold rolled dual phase steels made from different hot band structures showed that:

(i) The cold rolled dual phase structure derived from hot band with a spheroidized (tempered martensite) microstructure contained LTTP particles inside ferrite grains and unevenly distributed on ferrite grain boundaries.

(ii) From pearlitic hot band, LTTP were also formed within ferrite grains but were primarily concentrated in those areas occupied by the cold rolled pearlite colonies, to give incomplete ferrite grain boundary coverage.

(iii) Bainitic hot band produced the most uniform distribution of LTTP, with clean ferrite grain interiors and continuous grain boundary coverage.

(iv) Martensitic hot band gave a cold rolled dual phase microstructure containing microduplex regions of very small ferrite grains mixed with LTTP, as well as areas where larger ferrite grains had partial grain boundary coverage by LTTP.

(2) No hot band microstructure gave superior ductility at the resulting tensile strength level. However, using bainite-ferrite or martensite structures before cold rolling produced higher tensile strength than other structures, under the same processing conditions. This hot band advantage was larger at the lower strength levels associated with shorter intercritical annealing times and lower temperatures. Cold reduction effects did not interact with hot band starting structure.

(3) The bainite-ferrite hot band structure produced dual phase steel with a high endurance ratio in fully reversed bending fatigue tests. The superior fatigue properties of this steel were apparently due to the uniform distribution of LTTP on the ferrite grain boundaries.

\section{REFERENGES}

1) C. I. Garcia and A. J. Deardo: Met. Trans., 12A (1981), 521.

2) J.J. Yi, I.S. Kim and H. S. Choi: Met. Trans., 16A (1985), 1237.

3) D. Z. Yang, E. L. Brown, D. K. Matlock and G. Krauss: Met. Trans., 16A (1985), 1385.

4) G. R. Speich, V. A. Demarest and R. L. Miller: Met. Trans., 12A (1981) 1459.

5) W. R. Cribb and J. M. Rigsbee: Structure and Properties of Dual Phase Steels, ed. by R. A. Kot and J. W. Morris, Met. Soc. of AIME, (1979), 91.

6) D. K. Matlock, G. Krauss, L. F. Famos and G. S. Huppi Structure and Properties of Dual Phase Steels, ed. by R. A. Kot and J. W. Morris, Met. Soc. of AIME, (1979), 62.

7) H. Suzuki and A. J. McEvily: Met. Trans., 10A (1979), 475.

8) S. Tsuzuki Y. Sakamoto, M. Shimizu and T. Kunio: Trans. Japan Soc. Mech. Eng., 46 (1980), 870.

9) Y. Sakamoto, S. Tsuzuki, M. Shimizu and T. Kunio: Trans. Japan Soc. Mech. Eng., 47 (1981), 1257.

10) K. Yamada and T. Kunio: Trans. Jappan Soc. Mech. Eng., 45 (1979), 440.

11) V. B. Dutta, S. Suresh and R. O. Ritchie: Met. Trans., 15A (1984), 1193.

12) Y. Tomota, N. Tachibana, K. Tanabe and K. Kuroki: Tetsu-to-Hagané, 63 (1977), 962.

13) S. R. Mediratta, V. Ramaswamy and P. RamaRao: Int. J. Fatigue, 7 (1985), 107. 